\title{
Digitalization of the economy in the geography of the Republic of Uzbekistan
}

\author{
Madina A Raimjanova ${ }^{1}$, Dildora Kh Shadiyeva ${ }^{1}$, Laziz $S$ Zoyirov ${ }^{1}$, Rasulbek B Saidov ${ }^{1}$, \\ Mavluda T Askarova, ${ }^{2 *}$ \\ ${ }^{1}$ Tashkent Institute of Finance, 60A, A. Temur Street, 100000, Tashkent, Uzbekistan \\ ${ }^{2}$ Tashkent State University of Economics, 49, Uzbekistan street, 100003, Tashkent, Uzbekistan
}

\begin{abstract}
The article is devoted to an overview of the development and state of the digital economy of the Republic of Uzbekistan and the world as a whole. In particular, the role of information and communication technologies in enhancing the economic growth of countries and facilitating access to public services is being examined. The main components that stimulate the development of the country's digital economy (investments in information and communication technologies and their development, digital infrastructure, e-government) are revealed. When studying the material, the methods of analysis, observation, grouping, comparison of world experience in the development of information and communication technologies, and the digitization of the economy were used. A review of the main world ratings that are significant in the development of the digital economy is carried out and the place of the Republic of Uzbekistan in the ratings is revealed, a growth trend is noted. The analysis of the prospects of digital technologies in the Republic of Uzbekistan is carried out, the special role of the documents issued by the government on the development of the digital economy, as well as the organizations created that allow making innovative proposals, is noted. Based on the results of the study of the material, recommendations were made for improving the state of the digital economy in the country and in the world as a whole. These recommendations are also reflected in the regulatory documents on regulating the digitalization of the economy of the Republic of Uzbekistan.
\end{abstract}

\section{Introduction}

Modern society has confidently entered the threshold of the digital era, developing new spheres and professions, the basis for the development of the public administration system, the economic system, the private sector, the social structure of society and in general.

Competitiveness in the national market is mainly associated with the active development of information and communication technologies. The demand for information and communication technologies in the world is in great demand, the trade market for information and communication technologies is becoming an active sector of the world economy, all this has led to increased international competition.

\footnotetext{
*Corresponding author: indira91@inbox.ru
} 
The digital economy is a system of economic, social and cultural communication using digital technologies, including online services, distance learning, electronic payments, ecommerce. The digital economy covers many different industries: healthcare, transport, housing and utilities, finance, education, tourism, and more. The importance of the digital economy is revealed by the technologies of the digital economy (big data, artificial intelligence, block-chain and cloud technologies) [1,2].

The digital economy depends on the level of development of information and communication technologies, its development is assessed by certain indicators, this can be seen from Figure 1.

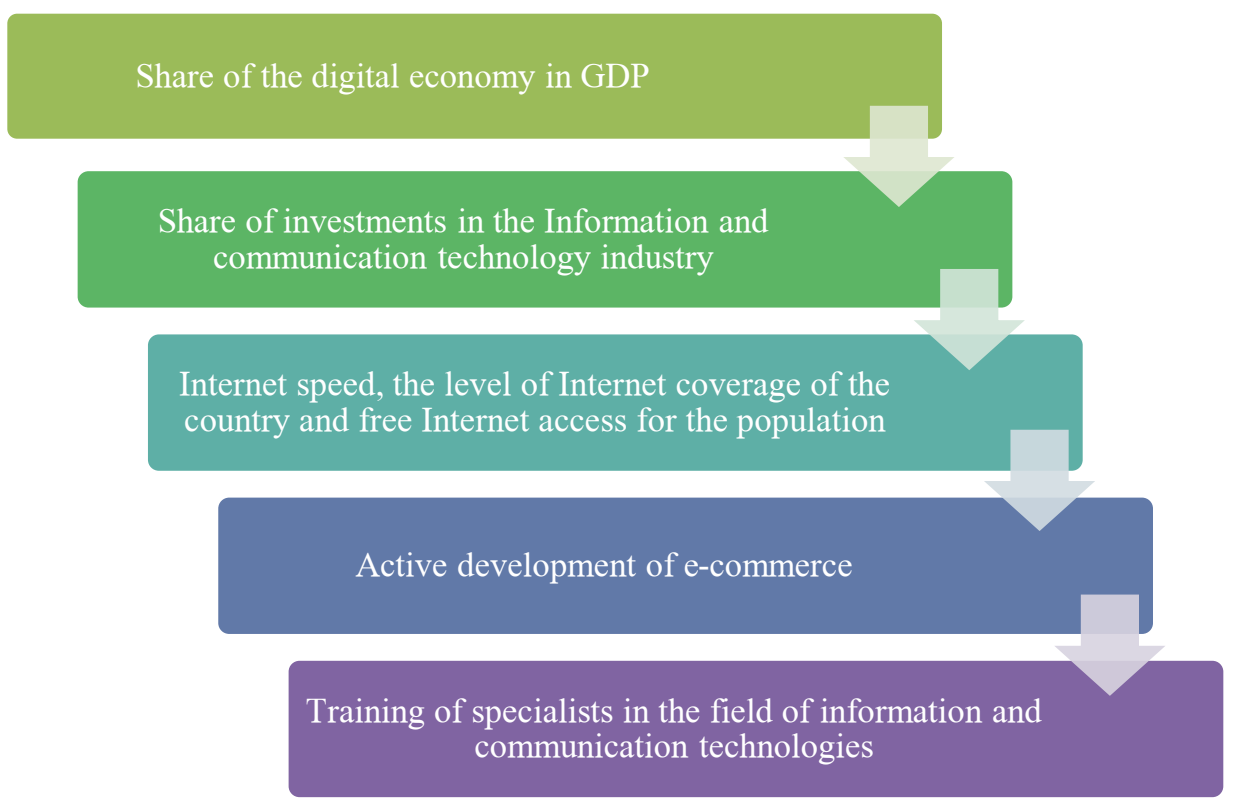

Fig. 1. Assessment of the development of the digital economy.

Economic transformation as a project was launched by the World Economic Forum in 2015. The aim of this project is to analyze the impact of digital technologies on the private sector and society, and to study digital opportunities in depth. Digital technologies have a profound impact on related industries and shape business models. In Uzbekistan, since 2015 , the active introduction of digital technologies into the country's economy has begun. [3] From 2015-2016, the project was aimed at such areas as logistics, media, consumer goods, electricity, cars and healthcare and their interaction with digital consumption, digital entrepreneurship, social and management platform. From 2016-2017, it has been implemented in the following areas: chemistry, mining and metallurgy, oil and gas, insurance, aviation and hospitality, professional services, telecommunications and retail [4].

It is planned to digitize more than 60 percent of the world's GDP by 2022. Over the next decade, the new value generated, which accounts for $70 \%$ of the economy, is planned to be based on digital platforms. At the moment, $50 \%$ of the world's population is not part of the digital economy [5].

Table 1. The share of the digital economy in GDP for 2019.

\begin{tabular}{|c|c|c|}
\hline № & Country & Share (percentage) \\
\hline 1 & United Kingdom & $12.4 \%$ \\
\hline 2 & South Korea & $8 \%$ \\
\hline 3 & China & $6.9 \%$ \\
\hline
\end{tabular}




\begin{tabular}{|l|c|c|}
\hline 4 & India & $5.6 \%$ \\
\hline 5 & Kazakhstan & $3.9 \%$ \\
\hline 6 & Russia & $2.8 \%$ \\
\hline 7 & Uzbekistan & $2.2 \%$ \\
\hline
\end{tabular}

As can be seen from Figure 2, the share of the digital economy in GDP in Uzbekistan is $2.2 \%$, with an average of $7-8 \%$. According to the draft developed in 2019, the Concept for the Development of the Electronic Government System in the Republic of Uzbekistan, it is forecasted to increase the share of information and communication technology services in GDP to 5 percent, and by 2030 - to 10 percent. [6]

\section{Methods}

The study of the digital economy is based on an empirical method that includes a review of annual statistics. International interdisciplinary scientific studies are being reviewed and analyzed. Assessing the impact of innovative factors on the full development of the digital economy in the country is not presented without the use of econometric methods and models. The research methodology used is multifactorial analysis.

The method of comparing data helps us to see the evolution of the Republic of Uzbekistan in the development of information and communication technologies and the digitalization of the economy. The use of the analysis method, the grouping allowed us to make recommendations related to the development of the digital economy in the world and in the Republic of Uzbekistan. [7,8]

\section{Result}

Investments in information and communication technologies, which contribute to the development of innovation potential, increase productivity, reduce costs and create new economic activities, and, most importantly, improve the quality of life of the population of the Republic, are of particular importance in the development of the economic potential of the Republic. [9]

Attracting investment in information and communication technologies in the development of the economy is a little difficult. Investments in the information and communication industry in the first half of 2019 increased by 2 times, compared to 2018 . But in 2018, in comparison with 2017, it decreased by 2 times, from 1.9 to 0.9 trillion. sums. The share of investments in "information and communication" in the total volume of investments in 2018 decreased by more than three times, compared to 2017, in the first half of 2019, compared to 2018, it did not change and amounted to $1.3 \%$. [10]

In 2017-2019, in the Republic of Uzbekistan, on average, about 200 million US dollars were invested every year. For example, in 2018, 1.3 trillion dollars were invested in the development of information and communication technologies in the United States, 499 million dollars in the PRC, and direct investments in Belarus amounted to 1.5 billion dollars. If it goes on like this, then worldwide spending on information and communication technologies will increase every year by $3.8 \%$ and by 2023 will reach 4.8 trillion dollars.

Another aspect in the development of the digital economy is digital infrastructure. The infrastructure is connected to the Internet. Infrastructure is measured by Internet speed and affordability. Internet speed is regulated by many factors, such as the number and type of networks, modern equipment, coverage of fiber-optic communication lines, information transmission in the network, high level of service providers. 


\section{Discusion}

According to the concept of development of the "Electronic Government" system, developed in 2019, it is forecasted to increase the bandwidth of the Internet from 1200 $\mathrm{GB} / \mathrm{s}$ to $4000 \mathrm{~GB} / \mathrm{s}$, and an increase in the number of Internet users among the population by 100 people. [11]

Table 2. Information and Communication Services Development Index for 2017.

\begin{tabular}{|c|c|c|c|c|c|}
\hline $\mathbf{2 0 1 7}$ & Country & Index & $\mathbf{2 0 1 6}$ & Index & $\begin{array}{c}\text { Rating } \\
\text { change }\end{array}$ \\
\hline 94 & Panama & 4.91 & 93 & 4.8 & - \\
\hline 95 & Uzbekistan & 4.9 & 103 & 4.48 & + \\
\hline 96 & Peru & 4.85 & 97 & 4.61 & + \\
\hline 97 & Ecuador & 4.84 & 101 & 4.52 & + \\
\hline 98 & Jamaica & 4.84 & 96 & 4.63 & - \\
\hline
\end{tabular}

In the modern world, the development of e-commerce is gaining importance. According to the Decree of the President of May 14, 2018 "On measures for the accelerated development of e-commerce", the National Register of e-commerce subjects e-tijorat.uz was created to motivate business entities in the field of e-commerce. The level of legal ecommerce in the Republic of Uzbekistan is just beginning to develop. In the second quarter of 2019, the number of e-commerce transactions amounted to 75.39 million, and the amount -3.515 trillion sums.

Also, we should not forget about the importance of modernizing the system of power. Namely, the introduction of information and communication technologies in the sphere of improving the activities of state authorities, deepening their communication with the population, the work of the "electronic government."

On the territory of the Republic of Uzbekistan, there is a platform for the provision of interactive public services - the Single portal of EPIGU -my.gov.uz. In 2017, in order to improve the conditions for the population to receive public services in electronic mode, a new version of the portal was launched. The number of services provided at EPIGU is 302 services, compared to 2015 , there were 260 of them.

There is a concept for the development of the "Electronic Government in 2019-2025" system, which provides for an increase in the share of public services of electronic format, from 37 percent to 80 percent, thus rising by 2025 in the E-Government Development Index from 81 st to 50 th place.

Table 3. Ranking of the world's countries in terms of e-government development for 2020.

\begin{tabular}{|c|c|c|}
\hline № & Country & Index \\
\hline 85 & Sri Lanka & 0.6708 \\
\hline 86 & Vietnam & 0.6667 \\
\hline 87 & Uzbekistan & 0.6665 \\
\hline 88 & Indonesia & 0.6612 \\
\hline 89 & Iran & 0.6593 \\
\hline 90 & Fiji & 0.6585 \\
\hline
\end{tabular}

The development of e-government has a great impact on the economies of countries. For example, in Denmark, the system of interactive public services saves an average of 10 20 percent of budget funds every year. Every person living in Denmark has a digital 
passport and a personal account, since 2015 all residents communicate with government agencies exclusively via the Internet, $95 \%$ of households have access to the network [12].

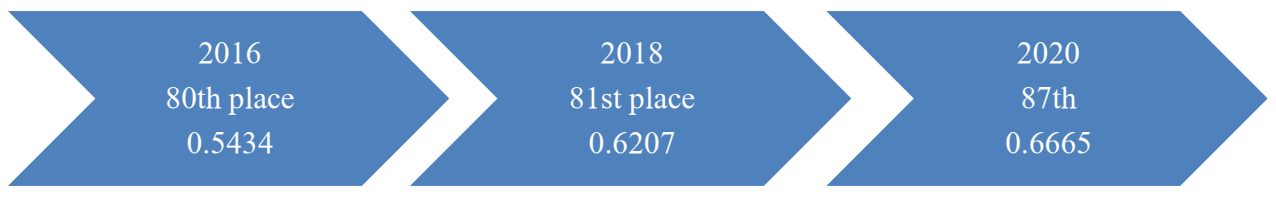

Fig. 2. The World's E-Government Development Index.

The e-government development index includes the average value of normalized indicators: the volume and quality of online services, the state of telecommunications infrastructure development, and domestic human capital.

\section{Conclusions}

The main role, we can say, in the development of the digital economy is played by private business, in parallel with innovation. At the same time, the state must provide all conditions and form infrastructure $[13,14]$.

The following areas have been chosen by the draft decision of the Cabinet of Ministers on the development of the digital economy:

1) take as a basis the necessary information systems and sources, programming and electronic implementation of services when identifying state and economic bodies, local self-government bodies

2) formation of technology markets and technology parks based on the digital economy, information technology market, and on the basis of public-private partnerships, in order to create favorable conditions for attracting foreign investment to the country

3) control of predictive telecommunications infrastructure, development of communication technologies and networks, introduction of modern telecommunications services

4) active use of e-commerce and economic services, e-commerce and digital development software

5) forming proposals and projections for the development of the national segment of the Internet, organizational, logistical and economic provision of digital media content [15].

6) creating "smart systems" to manage urban and regional infrastructure, transport logistics, safe and smart cities

7) improving the training system for qualified personnel.

On September 2, 2018, in the Republic of Uzbekistan, the Digital Trust Foundation was created in accordance with the Resolution of the President of the Republic of Uzbekistan, for the further development of the digital economy. The fund was created to develop forecasts of promising and strategically important projects for the development of the digital economy, and the implementation of block-chain technologies, education and training. With the help of the fund, it is planned to carry out measures to develop the concept of "Digital Uzbekistan" by 2030.

Our proposals are the motivation for the development of digital processes in the economy of the Republic of Uzbekistan, namely at the expense of:

- The state should organize common technology platforms, which integrate different organizations

- Do not forget about the modernization of the regulatory framework that contributes to the development of the digital economy, while taking into account the opinions of users, developers, and service providers 
- The state should join the overall process of digitization of the economy, constantly developing the system "Electronic Government" and increase the list of interactive services

- Motivate the introduction of information systems, electronic services in all private sectors, the creation of tax incentives for the development of digital technologies, and cross-border online trade

- Continuously improve the training system that can adapt to constantly updated digital technologies

- Protect against cyber threats, preserve the security of information from all kinds of criminal activities

- To study international experience, to cooperate in all areas of economic activity.

The development of information and communication technologies in the country, the introduction of digital technologies to increase productivity, reduce costs, increase production and profits [16].

\section{Reference}

1. S.S. Gulyamov, R.H. Ayupov, O.M. Abdullayev, G.R. Boltabayev, Block-chain Technologies in the Digital Economy

2. Analysis of the world experience of industrial development and approaches to the digital transformation of the industry of the member states of the Eurasian Economic Union - Moscow (2017)

3. The President's decree "Digital Trust" on the creation of a fund to support the development of the digital economy" PP-3927 (2018)

4. Decree of the President of the Republic of Uzbekistan of February 19, 2018 No. UP5349 No. 06/18/5349/0792 (National Database of legislation, Tashkent, 2018)

5. Presidential Decree No. 3832 of July 3, 2018 "On Measures to Develop the Digital Economy in the Republic of Uzbekistan"

6. S.M. Mirziyoyev, Message of President of the Republic of Uzbekistan Shavkat Mirziyoyev Oliy Mazhlisu. People's Word (2019)

7. On the state program to implement the strategy of action on the five priority areas of development of the Republic of Uzbekistan in 2017-2021 in the "year of active investment and social development." Decree of the President of the Republic of Uzbekistan for NO-5635

8. Sh. Yusupova, Z. Kadirova, S. Gazieva, M. Raimjanova, PalArch's Journal of Archaeology of Egypt. Egyptology 17(6), $3828 \quad$ - $3841 \quad$ (2020) https://archives.palarch.nl/index.php/jae/article/view/1499

9. I.V. Alexeyev, Current areas of scientific research: from theory to practice: materials $X$ Internar. science. practical. CNS Interactive Plus 4(10), $42-45$ (2016)

10. e-Government Knowledgebase, https://publicadministration.un.org/egovkb/enus/Data/Country-Information/id/186-Uzbekistan

11. V.P. Kupriyanovsky, S.A. Sinyagov, S.I. Lipatov, D.E. Namiot, A.O. Vorobyov, International Journal of Open Information Technologies 2, 26-33 (2016)

12. T.N. Yudina, Theoretical Economy 3, 12-16 (2016)

13. S.V. Shaytura, O.V. Kitova, Information marketing, 111-137 (2016)

14. R.S.C. Bhaskar Chakravorti, The Fletcher School, Tufts University (2017) https:/ /sites.tufts.edu/digitalplanet/files/2017/05/Digital_Planet_2017_FINAL.pdf 
15. The Digital Transformation of Industry "Electronic resource", https://bdi.eu/media/user_upload/ Digital_Transformation.pdf.

16. H. Dong, F.K. Hussain, Proceedings of the Third International Conference on Networking and Services (IEEE Computer Society, Washington, USA, 2017) 